\title{
The Islands of Threatened Species
}

UNTIL a few decades ago the wildlife of the Philippines was notable

by its abundance; now it is notable for its rarity; if the present destruction continues it will soon be notable for its absence, say Lee M. Talbot and Martha $\mathbf{H}$. Talbot in their report on the Philippines.* In fact "any species still surviving in the Philippines must be considered a threatened species". Wildlife was abundant until the war, when the Japanese occupation forced people to kill to eat. Since the war the population has increased enormously-the current rate is over one million persons a year; the number of firearms has increased and the game laws are not enforced. The considerable demand for animals for zoos and research centres has led to a profitable trade, and "exports of wildlife on permit have been actively encouraged by the Parks and Wildlife Office". Between 1955 and 1960 the total market value of wildlife exported was over $\$ 760,000$, "a terrific drain on the already depleted wildlife"; moreover, the figure takes no account of the mortality inflicted in the course of capture and removal. The tamarau, one of the world's rarest animals, is declining rapidly; it is openly hunted by the local cattlemen and by parties of wealthy sportsmen who fly to Mindoro from Manila; and the monkey-eating eagle, of which probably fewer than 100 survive, is in great demand for stuffed specimens (it is a status symbol in a Philippine home to have the largest one) and is illegally exported to zoos.

The problem of wildlife conservation is an integral part of the much greater problem of land use. Until recently the Philippines had some of the finest forest resources in the world, with a high growth rate and rapid reproduction. In the past 50 years these forests have been cut by more than half, and 80 per cent. of the reduction has taken place in the last 20 years. Today the situation is such that the remaining forests may be insufficient for long term needs. Moreover, only one sixth of the loss is in legitimate lumbering; the remainder is completely wasted in shift cultivation with no lasting benefit to anyone. This system, as old as the Stone Age, is called in the Philippines, kaiñgin. A cultivator, or kaiñginero, moves into an area of forest, ring-barks the trees over several hectares, cuts down those that are easy to fell early in the dry season and burns the rest later in the season when the ring barking has killed the larger trees. Though the ash temporarily enriches the soil, the long term effect of the fire, which destroys much of the organic matter in the top soil, is a severe loss of fertility. On the cleared ground the kainginero plants his crops, getting between one and three years' harvests, each one smaller than the last; he then moves on to repeat the destructive cycle somewhere else. Thus the soil and timber developed over the years are destroyed for a temporary and miserable subsistence for a few people.

The destruction of the watershed is another serious factor. The

* Renewable Natural Resources in the Philippines, for the South East Asia Project of the International Commission on National Parks of IUCN. 
function of a watershed is to act like a sponge, absorbing the rainfall in the wet seasons and releasing it at other times in underground water, springs, streams and rivers. But when the vegetation is cleared the area is converted from a sponge into "something more like a tin roof". Instead of soaking in, the rain flows immediately off the bare ground, carrying the soil with it, often bringing floods to the land below, and of course there is no stored water. The authors quote the case of the Ambeklao dam where in ten years silting has increased by 400 per cent. In another area, the President, in 1961, released part of the national park in Quezon Province for agriculture. Nine months later the Municipal Council, alarmed at the danger of floods, asked the President to revoke the order on the pant not yet cleared. But nothing was done, and by 1964 the destruction of the watershed had led to floods and a shortage of water in the dry season-and another petition to the President. The tropical rain of the Philippines, partly responsible for the lush natural vegetation, quickly washes away the soil once the cover has been removed, with the result that at the mouth of practically every river "there is a fresh and increasing delta of top soil and often of sub-soil washed off the lands above".

\section{The National Parks}

Of the 42 national parks, all have suffered some degree of harmful exploitation and only one, the Quezon National Park, has been maintained intact with an efficient Parks and Game Warden in charge working in cooperation with the local authorities. In the rest the fauna is hunted, the flora destroyed, and the squatters, shift cultivators and timber smugglers do their worst. In the Mount Data National Park, the resthouse, which once had an uninterrupted view of virgin forest, is now surrounded by cabbage gardens, and the water supply is threatened. In Basilan National Park lumbering has been allowed in 90 per cent. of the virgin forest and the remainder is being tackled.

The report declares that the most important single factor is the lack of understanding or awareness by the general public, and also some political leaders and government officials, of the importance of conservation: why worry about natural resources in the Atomic Age? is the attitude. It urges that education should be considered a first priority, not only in the schools, but using every other medium such as films, radio and television. For the wildlife, an inventory of wildlife resources is urgently necessary, together with research on the major problems, and an immediate concentration of effort to protect species known to be threatened with extinotion, for "it can safely be stated that (excluding rats) vintually any form of wildlife surviving today in the Philippines is threatened and, in general, the larger it is the more critical is its position".

\section{Correction}

The price of the record More Voices of African Birds was incorrectly stated in the August issue of ORYX. The correct price is $\$ 7.75$. 